\title{
Stage II Differentiated Thyroid Gland Carcinoma 45 Years and Older AJCC v7
}

National Cancer Institute

\section{Source}

National Cancer Institute. Stage II Differentiated Thyroid Gland Carcinoma 45 Years and

Older A/CC V7. NCI Thesaurus. Code C101542.

Stage II includes: T2, N0, M0. T2: Tumor more than $2 \mathrm{~cm}$ but not more than $4 \mathrm{~cm}$ in greatest dimension, limited to the thyroid gland. N0: No regional lymph node metastasis. M0: No evidence of distant metastasis. (from AJCC 7th Ed.) 